\title{
CALIBRATION FOR ARCHAEOLOGICAL AND ENVIRONMENTAL TERRESTRIAL SAMPLES IN THE TIME RANGE 26-50 KA CAL BP
}

\author{
C Bronk Ramsey ${ }^{1} \cdot \mathrm{E} \mathrm{M} \mathrm{Scott}^{2} \cdot \mathrm{J}$ van der Plicht $\mathrm{S}^{3,4}$
}

\begin{abstract}
For the older part of the radiocarbon dating range, the IntCal13 curve provides the "state of the art" for terrestrial calibration based on all available data. It is constructed from different records, each of which by themselves could be used as a "comparison tool," depending on the research objectives. This paper discusses the pros and cons of different approaches that can be taken when using ${ }^{14} \mathrm{C}$ dates from this time range where the agreement amongst the underlying data sets is poorer than in other time periods. The discussion is illustrated with example calibrations against IntCa09, IntCal13, and comparisons to the Suigetsu record. The examples and discussion are aimed at users of terrestrial ${ }^{14} \mathrm{C}$ dates, in particular Upper Paleolithic archaeologists and those working with environmental terrestrial materials in the same time range.
\end{abstract}

\section{INTRODUCTION}

Calibration of radiocarbon-dated samples over the period 14-50 ka cal BP historically has been problematic. The first calibration "curves" can hardly be called that (e.g. Vogel and Kronfeld 1997). During the last 15 years, however, considerable progress has been made, enabled by the introduction of accelerator mass spectrometry (AMS) with which large numbers of small samples could be dated, and then subsequent advances in the technique including smaller sample sizes and improved precision. The first data set spanning the complete ${ }^{14} \mathrm{C}$ dating range was based on varved sediments from Lake Suigetsu (Kitagawa and van der Plicht 1998) and further data sets followed after from other archives (e.g. Hughen et al. 2006; Hoffman et al. 2010; Edwards et al., submitted). However, these different records were clearly inconsistent over the oldest part of the ${ }^{14} \mathrm{C}$ dating range $(26-50 \mathrm{ka}$ cal BP). For this reason, IntCal04 (Reimer et al. 2004) terminated at $26 \mathrm{ka}$, and no recommendation was made for calibration beyond that age (NotCal04, van der Plicht et al. 2004). Nevertheless, various data sets were available, based on different archives. So, although there had been progress, very considerable uncertainties remained (Mellars 2006) and different curves and data sets could be selected by the user of ${ }^{14} \mathrm{C}$ (van Andel 2005; Bronk Ramsey et al. 2006). This situation prevented direct comparability of "calibrated" ${ }^{14} \mathrm{C}$ ages with each other and with ages measured by different techniques.

Once the reasons for some of the disparities in the data sets became better understood, the IntCal09 calibration curve (Reimer et al. 2009) was constructed. This was based on marine data sets (in particular, Cariaco Basin; Hughen et al. 2006) and corrected for estimated reservoir effects. The IntCal09 curve represented our best estimate of atmospheric ${ }^{14} \mathrm{C}$. Since then, reservoir corrections have changed because of improved understanding of the ocean system (Björck et al. 2003; Eiríksson et al. 2004; Bondevik et al. 2006), new records have become available such as speleothems (from Hulu Cave in particular; Southon et al. 2012) and, most importantly, because this is so far the only truly atmospheric data set, a new data set from Lake Suigetsu (Bronk Ramsey et al. 2012). The new IntCal13 calibration curve incorporates the information from all of the new data while retaining the information on which IntCal09 was based.

\footnotetext{
${ }^{1}$ Research Laboratory for Archaeology and the History of Art, University of Oxford, Oxford OX1 3QY, United Kingdom. Corresponding author. Email: christopher.ramsey@rlaha.ox.ac.uk.

${ }^{2}$ School of Mathematics and Statistics, University of Glasgow, Glasgow G12 8QQ, Scotland.

${ }^{3}$ Center for Isotope Research, Groningen University, Nijenborgh 4, 9747 AG Groningen, Netherlands.

${ }^{4}$ Faculty of Archaeology, Leiden University, P.O. Box 9515, 2300 RA Leiden, Netherlands.
} 


\section{INTCAL13: DISCUSSION OF THE NEW CURVE}

The new IntCal curve (Reimer et al. 2013, this issue) provides our best summary estimate for the mean tendency of the atmospheric or terrestrial ${ }^{14} \mathrm{C}$ reservoir, reconstructed from the different data sets using the chosen statistical procedure (Niu et al. 2013, this issue). Using this new curve across the various associated fields of research (archaeological and environmental) will allow calibrated results to be compared directly with each other and provide a common timescale across disciplines.

However, as has been pointed out before (van Andel 2005; Bronk Ramsey et al. 2006), it may be useful for the user community to compare their ${ }^{14} \mathrm{C}$ results to related individual data sets directly. In particular, users may wish to do this with the Lake Suigetsu record because of its purely terrestrial nature. It must be borne in mind, however, that any single data set also has its own potential problems and uncertainties. For Suigetsu, for example, small groups of single plant-macrofossil dates can have a significant effect on possible date ranges - especially where measurement uncertainties are higher in the lake sediment sequence (normally where the plant macrofossils are particularly small); the main effect, as we shall see, is normally to widen date ranges considerably, rather than give a very different central value. However, more fundamentally we should remember that Lake Suigetsu is still only a single terrestrial environmental record, and one key principle of the IntCal approach has always been that any point on the curve, and its uncertainty, should have input from multiple archives.

That said, IntCal13, in combining information from all available sources, does make some compromises and the impacts of these compromises are always going to be difficult to judge fully: there is no one right answer. It would of course be possible to produce a purely terrestrial curve and a purely marine curve. However, even a quick look at the data shows the problem with this approach: for example, for the period 34-40 ka BP the marine curve would imply higher ${ }^{14} \mathrm{C}$ levels in the ocean than in the atmosphere, which does make sense from a process point of view. In this sense, the marine data can justifiably inform the atmospheric curve and vice versa (albeit with wide uncertainties in the assumed ocean reservoir). These remaining discrepancies in the different records suggest that there must still be problems with the data in this time range, even if they are much smaller than they were when IntCal04 was constructed. We do not yet know the source of these problems, though we can speculate on different possible causes. The IntCal13 curve gains "borrowed strength" from averaging over the data from all archives.

The discrepancies between data sets are likely due to a number of factors, including errors in the underlying data sets over and above the quantified uncertainties and to underlying connections between and local environmental influences in the archives. These unquantified uncertainties have been allowed for in the curve-building process (Niu et al. 2013, this issue) but users of the calibration curve should also consider whether their own data has similar unquantified errors before calibration. To some extent, this is the task of the ${ }^{14} \mathrm{C}$ laboratories in quoting error terms that include all aspects of uncertainty (Scott 2013). However, in practice, especially over this time period, quantifying these errors may require site-specific research undertaken as a collaboration between ${ }^{14} \mathrm{C}$ specialists and those with site-specific expertise.

When considering the use of marine data in the calibration curve, we should remember that changes in the ocean circulation can result in variable upwelling of deep water (see e.g. Bondevik et al. 2006). Therefore, the ${ }^{14} \mathrm{C}$ record in marine organisms is attenuated and offset from the atmosphere. Fluctuations in the atmospheric ${ }^{14} \mathrm{C}$ levels become smoothed in marine archives (Stuiver and Braziunas 1993). This had led to speculation that ${ }^{14} \mathrm{C}$ calibration for atmospheric samples using marine curves (as in IntCal09) would be invalid around $40 \mathrm{ka} \mathrm{BP}$, the time of a significant decrease in the 
geomagnetic field strength known as the Laschamp event. However, given ${ }^{14} \mathrm{C}$ measurement uncertainties of hundreds of years, some authors have suggested that the Laschamp effect will have minimal effect on calibration (Talamo et al. 2012), while others argue it will have a large effect (Hajdas et al. 2011). As we will see, this former view is borne out in that the inclusion of terrestrial data into IntCal13 has not radically changed calibrations in this time range.

In some of the individual data sets, there is a great deal of detail, but over this period the IntCal13 curve is smooth and has less structure than IntCal09 in the age range 26-50 ka cal BP. We emphasize that it is not that there were no ${ }^{14} \mathrm{C}$ fluctuations during the glacial; it is that (at least within the framework of the quality of the data in hand coupled with statistical models adopted) we are unable to distinguish between the real ${ }^{14} \mathrm{C}$ fluctuations and those that are essentially measurement noise in the data. Those two factors, the statistical models and the data fluctuations, determine the constraints for the statistical random walk model used, and it is the resulting allowed spread in those realizations that gives rise to the smoothing, not the averaging per se.

In other words, IntCal13 is not perfect. It is rather a representation of our present understanding of many, sometimes conflicting data from different archives, and so is a work in progress that will be subject to change in the coming years when more data become available from various archives (in particular, the atmosphere). Ideally, this will be tree rings. For the Southern Hemisphere, this in principle exists for the complete ${ }^{14} \mathrm{C}$ dating range in the form of kauri wood (Balter 2006). But a firm dendrochronology needs to be established for these trees first for the Northern Hemisphere, which will take many years, and only then ${ }^{14} \mathrm{C}$ calibration will be truly absolute.

\section{EXAMPLE CALIBRATIONS FROM INTCAL13}

Figures 1 and 2 illustrate some of these points from a user point of view. Here we have plotted $95.4 \%$ and $68.2 \%$ probability ranges for typical dates in the $20-46 \mathrm{ka}{ }^{14} \mathrm{C}$ BP range calibrated using the IntCa109 and IntCal13 curves and compared against the Suigetsu 5-point weighted average data set (Bronk Ramsey et al. 2012). We have chosen "typical" error limits that users might obtain from the best sample material over this time range. The first point to note is that in most (though not all) cases the calibrated ranges from IntCal13 and IntCal09 overlap each other, at the $68.2 \%$ level. The second point to note is that the Suigetsu-derived and IntCal13 ranges always overlap, the main difference being that the Suigetsu data set results in multiple ranges (due to the wiggles seen in the curve and the variation in uncertainty of individual data points). The central tendency is very similar and it is likely that any modeled results will give similar age ranges within the limits of uncertainty placed upon them.

There are time ranges where there are significant offsets between the different records (especially in the range $27-32$ cal BP or $23-27{ }^{14} \mathrm{C} \mathrm{BP}$ ), but in these cases the IntCal13 calibration ranges are in agreement with those from comparison to the Suigetsu data set. For earlier periods where the raw data do show fluctuations not shown in the final curve, there are essentially no practical offsets in calibration. However, in these earlier periods, the averaged IntCal13 curve may give over-precise calibrated ages if some of the fluctuations seen in individual records are a real signal rather than measurement noise. This will probably have greatest impact for the interpretation of single dates or dates that span a narrow age range. Summarizing, in general, the calibrated values over this time range have not shifted significantly from IntCal09 despite considerable additions to the underlying data sets, which gives us confidence in the accuracy of the curve. 


\begin{tabular}{|c|c|c|c|c|}
\hline $\begin{array}{l}\text { IntCal09 }(20000,100) \\
\text { SG06_2012 }(20000,100) \\
\text { IntCal13 }(20000,100)\end{array}$ & & & & ब \\
\hline $\begin{array}{l}\text { IntCal09 }(21000,120) \\
\text { SG06_2012 }(21000,120) \\
\text { IntCal13 }(21000,120)\end{array}$ & & & बा & $\infty$ \\
\hline $\begin{array}{l}\text { IntCal09 }(22000,140) \\
\text { SG06_2012 }(22000,140) \\
\text { IntCal13 }(22000,140)\end{array}$ & & & $\begin{array}{l}\infty \\
0\end{array}$ & \\
\hline $\begin{array}{l}\text { IntCal09 }(23000,160) \\
\text { SG06_2012 }(23000,160) \\
\text { IntCal13 }(23000,160)\end{array}$ & & & $\begin{array}{r}\infty 0 \\
10 \\
0\end{array}$ & \\
\hline $\begin{array}{l}\text { IntCal09 }(24000,180) \\
\text { SG06_2012 }(24000,180) \\
\text { IntCal13 }(24000,180)\end{array}$ & & & $\begin{array}{l}\text { ब्व } \\
\text { ब }\end{array}$ & \\
\hline $\begin{array}{l}\text { IntCal09 }(25000,200) \\
\text { SG06_2012 }(25000,200) \\
\text { IntCal13 }(25000,200)\end{array}$ & & & ब & \\
\hline $\begin{array}{l}\text { IntCal09 }(26000,220) \\
\text { SG06_2012 }(26000,220) \\
\text { IntCal13 }(26000,220)\end{array}$ & & ब & 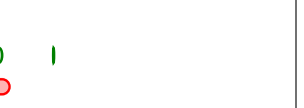 & \\
\hline $\begin{array}{l}\text { IntCal09 }(27000,240) \\
\text { SG06_2012 }(27000,240) \\
\text { IntCal13 }(27000,240)\end{array}$ & & $\begin{array}{l}\text { ब } \\
0 \text { ब }\end{array}$ & & \\
\hline $\begin{array}{l}\text { IntCal09 }(28000,260) \\
\text { SG06_2012 }(28000,260) \\
\text { IntCal13 }(28000,260)\end{array}$ & & 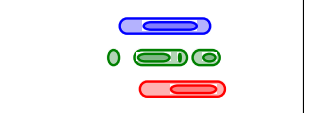 & & \\
\hline $\begin{array}{l}\text { IntCal09 }(29000,280) \\
\text { SG06_2012 }(29000,280) \\
\text { IntCal13 }(29000,280)\end{array}$ & & 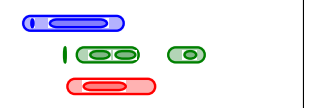 & & \\
\hline $\begin{array}{l}\text { IntCal09 }(30000,300) \\
\text { SG06_2012 }(30000,300) \\
\text { IntCal13 }(30000,300)\end{array}$ & & $\begin{array}{l}\text { वृ का } \\
\text { ल }\end{array}$ & & \\
\hline $\begin{array}{l}\text { IntCal09 }(31000,320) \\
\text { SG06_2012 }(31000,320) \\
\text { IntCal13 }(31000,320)\end{array}$ & बढ & $\infty_{00}$ & & \\
\hline $\begin{array}{l}\text { IntCal09 }(32000,340) \\
\text { SG06_2012 }(32000,340) \\
\text { IntCal13 }(32000,340)\end{array}$ & $\underbrace{\infty}_{0}$ & $\infty a$ & & \\
\hline
\end{tabular}

Figure 1 Example calibrations and comparisons of ${ }^{14} \mathrm{C}$ dates in the range $20-32 \mathrm{ka}{ }^{14} \mathrm{C} \mathrm{BP}$ (about $24-36 \mathrm{ka}$ cal BP). For each example date, we have calibrated using the IntCal09 calibration curve, compared to the Suigetsu 2012 data set (using the 5-point average from Bronk Ramsey et al. 2012), and calibrated using the IntCal13 calibration curve. The plot shows the $95.4 \%$ probability ranges as wide bars, and within those the $68.2 \%$ ranges as narrower bars. Uncertainties are chosen to be "typical" for single measurements. 


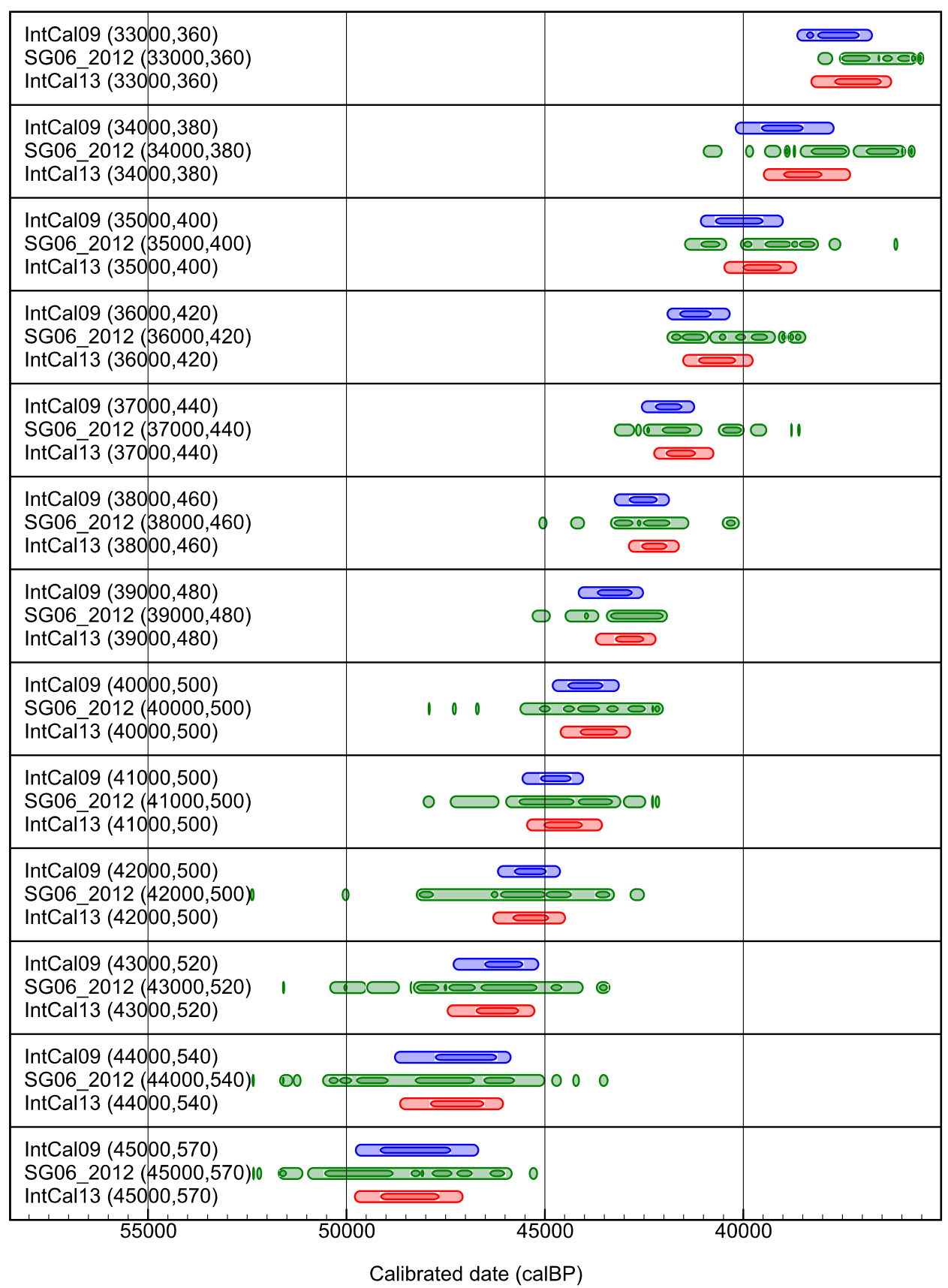

Figure 2 Example calibrations and comparisons of ${ }^{14} \mathrm{C}$ dates in the range $33-45 \mathrm{ka}{ }^{14} \mathrm{C} \mathrm{BP}$ (about $37-48 \mathrm{ka}$ cal BP). Format is as for Figure 1.

Some key time periods will be of interest to people in different fields. For example, ${ }^{14} \mathrm{C}$ dates in the range of $31,000{ }^{14} \mathrm{C} \mathrm{BP}$ are relevant to the unique paintings from Chauvet Cave in France (Valladas et al. 2001). 
Not so long ago, in the "NotCal" days, calibrated dates ranged between roughly 33 and $38 \mathrm{ka}$ cal BP, depending on the available calibration record chosen (Bard et al. 2004). Using IntCal09, the calibrated age becomes $35.0-35.5 \mathrm{ka}$ cal BP. As said before, in this age range, IntCal09 is based on marine records, in particular the Cariaco Basin. IntCal13 (or Suigetsu) yields significantly younger ages. This is caused by a) the introduction of Lake Suigetsu and b) correlation of the Cariaco data to an updated Hulu Cave record. Figure 1 shows the calibrations over this range; note that Lake Suigetsu in this time range is linked to the Bahamas speleothem (Hoffmann et al. 2010), and that the Cariaco data are plotted on the Hulu timescale (Edwards et al., submitted). As can be seen at these ages, both records deviate significantly from each other. Taking into account the measurement error of a typical ${ }^{14} \mathrm{C}$ date of this age of about $0.3 \mathrm{ka}{ }^{14} \mathrm{C}$ yr, IntCal13 shows that $31.0 \pm 0.3 \mathrm{ka} \mathrm{BP}$ calibrates into 34.6-35.2 ka cal BP; Suigetsu alone would give a range of 33.9-35.2 ka cal BP. Ranges for this example are quoted at $68.2 \%$ to highlight differences.

Another key period for archaeology and environmental science is the period around 40,000 cal BP where we have the Laschamp event (Muscheler et al. 2005), the Campanian Ignimbrite eruption, and the replacement of Neanderthals by anatomically modern humans (see e.g. Lowe et al. 2012). ${ }^{14} \mathrm{C}$ dates calibrated in this timescale (especially given the broad uncertainties associated with the individual measurements, due in part to the challenges of chemical pretreatment) will not be shifted very significantly regardless of the data set used (see Figure 2). However, the Suigetsu data set in this time range itself has considerable uncertainties in the ${ }^{14} \mathrm{C}$ measurements because of the small size of the macrofossils. There is also structure in the curve, which because of the uncertainties is largely eliminated in the averaged IntCal13 curve. Thus, the main effect of comparing directly to the Suigetsu record is to increase the number of possible matches, and there could be some argument for testing against individual records in this time range in applications where an absolute calibrated age is critical. As more extensive data sets become available, it is likely any extensive data set will map onto the different curves in much the same position, though this will only really be tested by researchers in different fields checking this assumption.

\section{CONCLUSIONS}

We conclude that the IntCal13 curve will provide the best tool for terrestrial calibration in this older time range. We would encourage those who wish to do so to also explore comparison to individual records, especially where they wish to look at their data in direct comparison with the climate information in the calibration records themselves (something that cannot be done with the compilation curve). However, the default position should be to use IntCal13 to provide comparability to other research in the field, and in practice, as the examples have shown, the differences seen will in most cases not be significant within the uncertainties of the calibration process itself.

\section{REFERENCES}

Balter M. 2006. Radiocarbon dating's final frontier. Science 313(5793):1560-3.

Bard E, Rostek F, Ménot-Combes G. 2004. A better radiocarbon clock. Science 303(5655):178-9.

Björck S, Koç N, Skog G. 2003. Consistently large marine reservoir ages in the Norwegian Sea during the Last Deglaciation. Quaternary Science Reviews 22(57):429-35.

Bondevik S, Mangerud J, Birks HH, Gulliksen S, Reimer P. 2006. Changes in North Atlantic radiocarbon reservoir ages during the Allerød and Younger Dryas. Science 312(5779):1514-7.

Bronk Ramsey C, Buck CE, Manning SW, Reimer P, van der Plicht J. 2006. Developments in radiocarbon calibration for archaeology. Antiquity 80(310):783-8.

Bronk Ramsey C, Staff RA, Bryant CL, Brock F, Kitagawa H, van der Plicht J, Schlolaut G, Marshall MH, Brauer A, Lamb HF, Payne RL, Tarasov PE, Haraguchi T, Gotanda K, Yonenobu H, Yokoyama Y, Tada R, Nakagawa T. 2012. A complete terrestrial radiocarbon record for 11.2 to $52.8 \mathrm{kyr}$ B.P. Science $338(6105)$ : $370-4$.

Edwards RL, Cheng H, Wang YJ, Yuan DX, Kelly MJ, Kong XG, Wang XF, Burnett A, Smith E. 2013. A re- 
fined Hulu and Dongge Cave climate record and the timing of the climate change during the last glacial cycle. Earth and Planetary Science Letters, submitted.

Eiríksson J, Larsen G, Knudsen KL, Heinemeier J, Símonarson LA. 2004. Marine reservoir age variability and water mass distribution in the Iceland Sea. Quaternary Science Reviews 23(20-22):2247-68.

Hajdas I, Taricco C, Bonani G, Beer J, Bernasconi SM, Wacker L. 2011. Anomalous radiocarbon ages found in Campanian Ignimbrite deposit of the Mediterranean deep-sea core Ct85-5. Radiocarbon 53(4):575-83.

Hoffmann DL, Beck JW, Richards DA, Smart PL, Singarayer JS, Ketchmark T, Hawkesworth CJ. 2010. Towards radiocarbon calibration beyond $28 \mathrm{ka}$ using speleothems from the Bahamas. Earth and Planetary Science Letters 289(1-2):1-10.

Hughen K, Southon J, Lehman S, Bertrand C, Turnbull J. 2006. Marine-derived ${ }^{14} \mathrm{C}$ calibration and activity record for the past 50,000 years updated from the Cariaco Basin. Quaternary Science Reviews 25(23-24): 3216-27.

Kitagawa H, van der Plicht J. 1998. Atmospheric radiocarbon calibration to 45,000 yr B.P.: Late Glacial fluctuations and cosmogenic isotope production. Science 279(5354):1187-90.

Lowe J, Barton N, Blockley S, Bronk Ramsey C, Cullen VL, Davies W, Gamble C, Grant K, Hardiman M, Housley R, Lane CS, Lee S, Lewis M, MacLeod A, Menzies M, Müller W, Pollard M, Price C, Roberts AP, Rohling EJ, Satow C, Smith VC, Stringer CB, Tomlinson EL, White D, Albert P, Arienzo I, Barker G, Boric S, Carandente A, Civetta L, Ferrier C, Guadelli J-L, Karkanas P, Koumouzelis M, Müller UC, Orsi G, Pross J, Rosi M, Shalamanov-Korobar L, Sirakov N, Tzedakis PC. 2012. Volcanic ash layers illuminate the resilience of Neanderthals and early modern humans to natural hazards. Proceedings of the National Academy of Sciences of the USA 109(34):13,532-7.

Mellars P. 2006. A new radiocarbon revolution and the dispersal of modern humans in Eurasia. Nature 439(7079):931-5.

Muscheler R, Beer J, Kubik PW, Synal H-A. 2005. Geomagnetic field intensity during the last 60,000 years based on ${ }^{10} \mathrm{Be}$ and ${ }^{36} \mathrm{Cl}$ from the Summit ice cores and ${ }^{14}$ C. Quaternary Science Reviews 24(16-17):184960

Niu M, Heaton TJ, Blackwell PG, Buck CE. 2013. The Bayesian approach to radiocarbon calibration curve estimation: the IntCal13, Marine13, and SHCal13 methodologies. Radiocarbon 55(4), this issue.

Reimer PJ, Baillie MGL, Bard E, Bayliss A, Beck WJ, Bertrand C, Blackwell PG, Buck CE, Burr GS, Cutler KB, Damon PE, Edwards RL, Fairbanks RG, Friedrich M, Guilderson TP, Hughen KA, Kromer B, McCormac FG, Manning S, Bronk Ramsey C, Reimer RW,
Remmele S, Southon JR, Stuiver M, Talamo S, Taylor FW, van der Plicht J, Weyhenmeyer CE. 2004. IntCal04 terrestrial radiocarbon age calibration, 0-26 cal kyr BP. Radiocarbon 46(3):1029-58.

Reimer PJ, Baillie MGL, Bard E, Bayliss A, Beck JW, Blackwell PG, Bronk Ramsey C, Buck CE, Burr GS, Edwards RL, Friedrich M, Grootes PM, Guilderson TP, Hajdas I, Heaton TJ, Hogg AG, Hughen KA, Kaiser KF, Kromer B, McCormac FG, Manning SW, Reimer RW, Richards DA, Southon JR, Talamo S, Turney CSM, van der Plicht J, Weyhenmeyer CE. 2009. IntCa109 and Marine09 radiocarbon age calibration curves, 0-50,000 years cal BP. Radiocarbon 51(4): 1111-50.

Reimer PJ, Bard E, Bayliss A, Beck JW, Blackwell PG, Bronk Ramsey C, Buck CE, Cheng H, Edwards RL, Friedrich M, Grootes PM, Guilderson TP, Haflidason H, Hajdas I, Hatté C, Heaton TJ, Hoffman DL, Hogg AG, Hughen KA, Kaiser KF, Kromer B, Manning SW, Niu M, Reimer RW, Richards DA, Scott EM, Southon JR, Staff RA, Turney CSM, van der Plicht J. 2013. IntCal13 and Marine13 radiocarbon age calibration curves $0-50,000$ years cal BP. Radiocarbon 55(4), this issue.

Scott EM. 2013. Radiocarbon dating: sources of error. In: Elias S, Mock C, editors. Encyclopedia of Quaternary Science. Amsterdam: Elsevier. p 324-8.

Southon J, Noronha AL, Cheng H, Edwards RL, Wang Y. 2012. A high-resolution record of atmospheric ${ }^{14} \mathrm{C}$ based on Hulu Cave speleothem H82. Quaternary Science Reviews 33:32-41.

Stuiver M, Braziunas TF. 1993. Modeling atmospheric ${ }^{14} \mathrm{C}$ influences and ${ }^{14} \mathrm{C}$ ages of marine samples to 10,000 BC. Radiocarbon 35(1):137-89.

Talamo S, Hughen KA, Kromer B, Reimer PJ. 2012. Debates over Palaeolithic chronology - the reliability of ${ }^{14} \mathrm{C}$ is confirmed. Journal of Archaeological Science 39(7):2464-7.

Valladas H, Clottes J, Geneste J-M, Garcia MA, Arnold M, Cachier H, Tisnérat-Laborde N. 2001. Palaeolithic paintings: evolution of prehistoric cave art. Nature 413(6855):479.

van Andel TH. 2005. The ownership of time: approved ${ }^{14} \mathrm{C}$ calibration or freedom of choice? Antiquity 79(306):944-8.

van der Plicht J, Beck JW, Bard E, Baillie MGL, Blackwell PG, Buck CE, Friedrich M, Guilderson TP, Hughen KA, Kromer B, McCormac FG, Bronk Ramsey C, Reimer PJ, Reimer RW, Remmele S, Richards DA, Southon JR, Stuiver M, Weyhenmeyer CE. 2004. NotCal04-comparison/calibration ${ }^{14} \mathrm{C}$ records $26-$ 50 cal kyr BP. Radiocarbon 46(3):1225-38.

Vogel JC, Kronfeld J. 1997. Calibration of radiocarbon dates for the Late Pleistocene using U/Th dates on stalagmites. Radiocarbon 39(1):27-32. 